\title{
The 2004 EU Enlargement as an Outcome of Public Policies: The Impact of Intra-EU Mobility on Central and Eastern European Sending Countries
}

\author{
Izabela Grabowska \\ SWPS University of Social Sciences and Humanities in Warsaw, Institute of Social Sciences, \\ Mobility Research Group \\ E-mail: izabela.grabowska@swps.edu.pl
}

This article analyses the impact of mobility on sending CEE countries after the biggest EU enlargement of 2004 with some reference to the EU enlargement of 2007. It is presented on the fifteenth anniversary of the biggest historical EU enlargement with a disclaimer that economic and social changes are still enduring. The aim of this article is to explain the interlinked economic and social impacts of EU enlargements on CEE sending countries relating to: GDP, wages, economic remittances, welfare systems and employment, human capital (tangible and intangible), social remittances and social mobility. It is proved here, that exploring and exploiting the complex catalogue of available arguments and findings across CEE countries, EU enlargements can be seen as outcomes of a set of top-down public policies with their regulation (EU law), distribution (four freedoms) and redistribution functions (EU funds) along with bottom-up activities and developments of migrants themselves.

Keywords: EU enlargement, mobility, impact, public policy.

\section{Introduction}

This article analyses the impact of mobility on Central and Eastern European (CEE) sending countries and migrants themselves after the European Union (EU) enlargement of 2004 with some references to the EU enlargement of 2007. The article is presented on the fifteenth anniversary of the EU enlargement of 2004, the biggest in history, with a disclaimer that the economic and social changes and adjustments are still ongoing, proceeding at different tempos in individual CEE countries.

When we understand public policy as a kind of system of laws, regulations, measures, actions, and funding priorities, with special attention to social policy (Vargas-Hernandez et al., 2011), we can consider the EU enlargements as outcomes of set of public policies relating to regulation, distribution and redistribution (Aranson and Ordeshook, 1981). These effects are predominantly realised by: the harmonisation of national legislations with EU standards (regulation), the investments in human capital and infrastructure through the European Funds (redistribution), and the four freedoms of movement within the European Economic Area (EEA): people, services, capital and goods (distribution). However, by analysing the direct and indirect effects of the EU enlargements on sending societies and migrants themselves, we can see how top-down and bottom-up developments of EU enlargements can interplay. 
The EU enlargements have resulted in millions of migrants moving from CEE countries to Western and Northern European countries. This substantial intra-EU migration based on the key principle of freedom of movement has come under attack, especially after the 2008 economic crisis. Engbersen et al. (2017), from the perspective of receiving societies, speak of a contested intra-EU migration regime that gave rise to debates about strains on public services (social security, housing, health care) and growing job competition between mobile workers and established workers in migrant-receiving countries (see also Scholten and Van Ostaijen, 2018).

Engbersen et al. (2017: 340; after Taylor-Gooby, 1996: 200) define the intra-EU mobility regime as 'a particular constellation of economic, political and social arrangements that tend to nurture a particular mobility system, which in turn supports a particular pattern of stratification and thus feeds back into its own stability.' They argue that the free movement of persons was considered of crucial importance to achieve economic and social cohesion and to reduce social inequalities within the EU.

The aims of this article are: (1) to review the socio-economic impact of the EU enlargements on CEE sending countries and migrants themselves; and (2) to identify research consensus, gaps and uncertainties about these effects in order to determine their implications for policies. It is assumed here that by exploring the complex catalogue of available arguments and findings across CEE countries, EU enlargements are the outcomes of set of public policies relating to regulation, distribution and redistribution. The mobility of people from CEE countries might be also considered as an indirect response to the lack of public policies in their countries at the time of their departure. It also relates to macromicro relations where migrants were able to create opportunities and drive the process, rather than simply respond to macro developments.

The structure of the article is as follows. First we give a short overview of the scope and nature of intra-EU mobility from CEE. Then we present the methodological approach and we summarise it in an overview table of selected indicators and sources. Finally, we present the outcomes of the review of the economic and social consequences of intra-EU mobility on CEE countries with the selected implications for policy.

\section{The nature and extent of intra-EU migration from CEE}

In her article Grzymała-Kazłowska (2013: 5) attempted to summarise the vast literature on CEE migration issues in order to understand what CEE is and what countries are covered by this frame.

\footnotetext{
'Although Central and Eastern Europe (CEE) is sometimes referred to as a buffer zone (cf. Iglicka, 2001) because of its location between the huge Asian continent and Western Europe, it is also an area of intense and diverse migration flows both internal and external. In a broader sense, the region of Central and Eastern Europe may include countries of the Visegrád Group (Czech Republic, Hungary, Poland and Slovakia), the states of the former USSR, as well as southern post-communist states, Bulgaria and Romania, and even the states of the former Yugoslavia and Albania (cf. Okólski, 2004; Castles and Miller, 2003)' (Grzymała-Kazłowska, 2013: 5).
}

In this article we predominantly cover the CEE countries - EU8 - which joined the EU in $2004^{1}$ with some reference to those who joined in $2007^{2}$. The EU enlargements of 2004 and 2007 prompted new migration flows in Europe. Fassmann et al. (2014) calculated 
that, by 2011, almost five million citizens from CEE countries resided in the 'old EU' (cf. Okólski and Salt, 2014). Their movements were mostly labour market-driven (Fihel et al., 2006) which means that they mainly responded to the current demands and supplies of the labour markets (Krisjane et al., 2016 - for Latvia), regardless of their formal qualifications. Geddes (2003: 192) explains for instance that the response to migration opportunities 'has less to do with the personality or character of individual migrants' but much more to do with 'the perspectives on international migration and migrants by institutions and organizations at the national and international level'.

The outflow of people is not evenly distributed across the CEE countries. The World Bank (2006) came up with the first estimates soon after the 2004 EU enlargement, when the outflows peaked: Lithuania's working age population shrank by 3.3 per cent, Latvia's by 2.4 per cent, Slovakia's by 1.3 per cent, Poland's by 1.2 per cent, and Estonia's 1.1 per cent. Most of these migrants went to the United Kingdom, Sweden and Ireland, who were the first to open their labour markets to workers from EU10 ${ }^{3}$ although the UK was an exception that $A 8^{4}$ migrants still needed to register on the Worker Registration Scheme $(W R S)^{5}$. Three years later, Kahanec et al. (2009) calculated that between 2004 and 2008, the labour force in the whole of EU 8/A8 had shrunk by 1.16 per cent. Particularly affected in their study were: Poland (1.77 per cent of its labour force), Slovakia (1.34 per cent of its labour force), Lithuania (1.14 per cent of its labour force) and Lithuania (1.14 per cent of its labour force).

Compared to migration in the post-communist system transition period (1989-2003), post-accession migration was characterised by a higher intensity and a greater diversity of migrant strategies (Grzymała-Kazłowska, 2013). The flows following the enlargements of 2004 and 2007, especially, are treated as historically new phenomena in the EU in view of their multifaceted character; their characteristics include the co-existence of different forms of mobility (commuting, short-term, long-term, circular, permanent, selfemployment, posted workers ${ }^{6}$ ) and a big share of well-educated people (e.g. Galgóczi and Leschke, 2012; Engbersen and Jansen, 2013).

The unexpected scale of movement within the enlarged EU of the last fifteen years gives rise to questions about its economic and social effects and implications for public policy in sending countries. The majority of literature documenting the impact of EU enlargements focuses on receiving countries: this article fills in the gap by focusing on sending countries.

\section{The methodological approach}

To analyse the socio-economic impact of intra-EU mobility on sending countries and migrants themselves, we employed a desk research approach based on a literature review (Newell, 1998) of findings published worldwide between 2005 and 2018 in scientific journals articles, research monographs, chapters in edited volumes and open access policy reports produced through a peer-review process. The aim of this analysis was to create a qualitative overview of how others have addressed the issue and how main lines of explanations are narrated in order to uncover what scholarly knowledge has been produced across disciplines (Repko and Szostak, 2017: 126). The topic of the impact of EU enlargements requires literature searches across several disciplines (Newell, 1998): economics, sociology and migration studies. While conducting the analysis, we avoided normative judgements on the impact of intra-EU mobility on the sending countries. Our 
Table 1 An overview table describing impact indicators, countries of study and the referenced literature

\begin{tabular}{|c|c|c|}
\hline Indicator & Countries & Selected literature \\
\hline $\begin{array}{l}\text { GDP, wages, } \\
\text { economic } \\
\text { remittances, } \\
\text { welfare } \\
\text { systems } \\
\text { and } \\
\text { employment }\end{array}$ & $\begin{array}{l}\text { Sending countries: Poland, } \\
\text { Slovakia, Lithuania, Romania, } \\
\text { Bulgaria, Latvia, Estonia, Czech } \\
\text { Republic } \\
\text { CEE return migration }\end{array}$ & $\begin{array}{l}\text { Fihel et al. (2006); Kaczmarczyk and } \\
\text { Okólski (2008); D'Auria et al. } \\
\text { (2008); Kahanec et al. (2009); } \\
\text { Bodvarsson and Van den Berg } \\
\text { (2009); Nowaczek (2010); } \\
\text { Markova (2010); Hazans (2013); } \\
\text { Holland et al. (2011); Mereuta } \\
\text { (2012); Martin and Radu (2012); } \\
\text { Kurekova (2013); Gjini and Moisiu } \\
\text { (2013); Goschin (2014); } \\
\text { Voitchovsky (2014); Austers } \\
\text { (2015); Barslund et al. (2015); } \\
\text { Kaczmarczyk (2018). }\end{array}$ \\
\hline $\begin{array}{l}\text { Human capital: } \\
\text { tangible and } \\
\text { intangible }\end{array}$ & $\begin{array}{l}\text { Poland, Baltic States, Romania, } \\
\text { Slovakia }\end{array}$ & $\begin{array}{l}\text { Baláž and Williams (2004); Williams } \\
\text { and Baláž (2005); Currie (2007); } \\
\text { Kaczmarczyk and Okólski (2008); } \\
\text { Thaut (2009); Anacka and Okólski } \\
\text { 2010; Galgóczi and Leschke } \\
\text { (2012); Bélorgey et al. (2012); Tilea } \\
\text { et al. (2013); Nowicka (2012, } \\
\text { 2014); Voitchovsky (2014); } \\
\text { Grabowska (2016b); Fihel et al. } \\
\text { (2018); White et al. (2018). }\end{array}$ \\
\hline $\begin{array}{l}\text { Social } \\
\text { remittances } \\
\text { and social } \\
\text { mobility }\end{array}$ & Poland, Romania, Estonia & $\begin{array}{l}\text { Elrick (2008); Sandu 2010; Masso } \\
\text { et al. (2013); Gawlewicz (2015); } \\
\text { Grabowska (2016a); White (2016); } \\
\text { Krzyżowski (2016); Grabowska and } \\
\text { Garapich (2016a; 2016b); } \\
\text { Grabowska and Engbersen (2016); } \\
\text { Grabowska (2016b); Grabowska } \\
\text { et al. (2017); Grabowska (2018a, } \\
\text { 2018b); White et al. (2018). }\end{array}$ \\
\hline
\end{tabular}

Source: own elaboration.

intention was to examine the processes discussed across both economic and social arguments, allowing the picture that emerged as a result to speak for itself (for the selection of the literature see Table 1).

The aim of this desk research analysis was to synthetically juxtapose arguments on the impact of the EU enlargements on the sending countries and migrants themselves and shift the debate to 'the settled post-enlargement era'. It was also intended to systematically identify research uncertainties, gaps and consensus on these effects which can provide implications for policy. 


\section{Economic impact}

The existing studies on intra-EU mobility show that the overall economic impact of postaccession mobility has complemented the ongoing changes, but with both expected and unexpected effects. At the level of the individual CEE sending countries, the overall economic impact of migration is predominately determined by the pace of adjustment of labour and capital, by the skill profiles of the migrant and native populations, and by the real size of the migration flows (D'Auria et al., 2008).

Kahanec et al. (2009) found that the economic impact of post-enlargement migration, on balance between receiving and sending countries, was very low but positive. Between 2004 and 2009, at the early post-enlargement stage, free movement brought a total increase of 0.2 per cent of GDP (about twenty-four billion euros). However, it appears that receiving countries seem to benefit more than sending countries; the total benefit for EU15 countries amounted to 0.26 per cent of their GDP, while the sending countries of EU8 lost 1.1 per cent of their GDP. This data did not cover Bulgaria and Romania. The biggest profiteers of the post-accession freedom of movement were Ireland (2.93 per cent of GDP) and the UK (0.89 per cent of GDP). The biggest losers but also the biggest senders were Poland ( -1.94 per cent of GDP), Slovakia ( -1.51 per cent of GDP) and Lithuania $(-1.15$ per cent of GDP).

Another study by Holland et al. (2011) found that the potential economic output of the EU has increased by 0.8 per cent due to migration from EU $10^{7}$ (Malta and Cyprus were not included in this study). The countries with the highest positive potential outputs were Ireland ( 3 per cent) and the UK (1.2 per cent). The countries with the highest negative outputs were Romania, Bulgaria and Lithuania. The modelling performed by Holland et al. (2011) shows that, in the longer term, the outflow of people from CEE countries may not only result in some loss of growth potential (the greatest losses are: Lithuania, -6 per cent; Romania, -10.6 per cent; Bulgaria, -5.4 per cent; and Latvia, -3.3 per cent) but also in a reduction of income per capita.

According to Barslund et al. (2015), wage difference is the main driver behind mobility in the EU and most regional shocks are absorbed by shifts in labour market participation rates, not by labour mobility. Kahanec et al. (2009) claim that it is not obvious that emigration causes the labour markets of sending countries to become more employee-driven, with wages increases as a result. Whether or not this is the case, it depends on the nature of the migrants. The departure of highly educated workers increases the wages in the high-skilled labour market and increases unemployment in the low-skilled labour market (Kahanec et al., 2009). The departure of low-skilled decreases unemployment, with negative effects on wages in the high-skilled sector. Kahanec et al. (2009) also claim that migration increases the risk of wage imbalances as a result of labour shortages. However, in the long run, investments will adjust to the new situation. Contrary to the expectation that a reduction in the labour force will push wages up, and higher wages will increase labour participation (e.g. see Beblavy et al., 2014; Veselková et al., 2014), the positive effect is only short-term.

There is also a wage effect of return migrants on their countries of origin. Martin and Radu (2012) collated EU-LFS data about return migration in CEE countries. They analysed the income premium for work experience abroad. Consistent with previous results, they found that the income premium for work abroad ranges between 10 per cent and 
45 per cent. Return migration accelerated after the global financial crisis of 2007-2009, with Romania, Lithuania and Poland being the main gainers (Barslund et al., 2015).

CEE migrants send part of their incomes back home, predominantly to support their families, thereby indirectly supporting the economy of their country of origin as well (Markova, 2010). A general rule about economic remittances is that the more temporary and circular migration flows are, the more money is remitted to the sending countries (OECD, 2006). It is also worth comparing these remittances with the inflow of EU Funds to the CEE countries (Barbone et al., 2012 and cf. Grabowska et al., 2017; White et al., 2018) due to their redistributive function mentioned at the beginning of this article.

According to Bodvarsson and Van den Berg (2009), when migrants remit a substantial part of their earnings from abroad to their home countries, the influx of new money in the market can lead to an increase in the total demand for labour in the sending country. During the first phase after the 2004 and 2007 EU enlargements, the total amount of money remitted from EU15 to CEE countries was higher. For instance, in Poland, migration money exceeded the inflow of money from the European Structural Funds (Barbone et al., 2012) until 2007. Following the enlargements, the duration of migrants' stays gradually increased, and they started to unite with their families, bringing them to the destination countries, and to adopt more individualistic life styles which causes decreasing amount of economic remittances.

There are at least two contradictory studies about the effects of economic remittances on CEE countries. Goschin (2014) argues that economic remittances are capital flows and have macroeconomic growth potential for CEE countries. According to panel aggregate data that covered ten CEE countries in the period of 1995-2011, the main overall results of analyses are the significant positive influences of remittances on both absolute and relative GDP growth. Another study by Gjini and Moisiu (2013) based on balanced panel data from twelve CEE countries over the period 1996-2010 found that remittances had negative effects on GDP growth in these CEE countries during the period studied. In the latter case, an increase in remittances by 10 per cent decreased output by approximately 0.9 per cent. The explanations for these divergent findings, and therefore research uncertainties, are complex and may relate to a variety of effects across CEE countries, such as welfare effects - how migration money is spent and how it impacts on the economic activity of non-migrating household members - and the labour market status of migrants after their return: some migrants after return withdraw intentionally from economic activity for a while (Fihel and Grabowska-Lusinska, 2014).

There is much evidence that economic remittances to CEE countries are primarily spent on consumption. This is best seen on the meso level of local communities (BulgariaMarkova, 2010, Romania - Sandu, 2010; Poland - Wieruszewska, 2010). Economic remittances may also create specific dilemmas for households, because, by boosting purchasing power, they might reduce the incentive to seek employment (Austers, 2015).

The existing studies have not produced any evidence of migration with the aim to get welfare in the EU only (Austers, 2015) (discussion also in e.g. Nowaczek, 2010). It seems that the welfare systems of the receiving countries profited more as a result of postaccession enlargements than the welfare systems of the sending countries, since migrants are primarily young people with high labour market participation rates. They have much less need of welfare arrangements than the older segments of the receiving populations (Austers, 2015). Furthermore, it seems that the outflow of people, especially young people, has a detrimental effect on the welfare systems of sending countries, taking also into 
account ageing processes. However, it is possible that, in the short term, the welfare losses of the sending countries are somehow balanced by the welfare benefits transferred by migrants (mostly unemployment and children benefits). Nevertheless, the threat exists that the outflow of people, especially the young and well-educated, may hamper the sustainability of social protection systems (pension and medical care) (see e.g. Mereuta, 2012 for Romania). Also relevant in this context is the model constructed for Poland by Fihel et al. (2018), which showed that aging of the population would have occurred either way, regardless of whether the accession triggered a migration outflow or not.

A different explanation focuses on the concept of modernisation of the sending labour markets via migratory outflows. Kaczmarczyk and Okólski (2008) claimed that CEE countries need to experience so-called crowding out (Layard et al., 1994), which can be facilitated by out-migration. They claim that the majority of European countries went through this process in the late nineteenth century. However, countries like Poland have had over-surpluses of labour in the agricultural sector, where some parts of local economies remain as relics of subsistence or natural economy. In this sector people have little chance of changing their socio-economic status unless they abandon the sector by migrating elsewhere. Analysis of migratory selectivity patterns supported this crowding out hypothesis. Kaczmarczyk and Okólski (2008) showed that, at least in the first phase following the 2004 EU enlargement, people from economically disadvantaged small towns and villages, with low employment opportunities and relatively large semisubsistence sector, had a stronger tendency to migrate. Kaczmarczyk (2018: 105) summarises the impact of post-accession migratory outflows on the Polish labour market:

\footnotetext{
'Empirical evidence on Poland demonstrates that in a labour market that is encumbered by serious structural maladjustments and that is undergoing major demographic change, even short-term relations between the outflow of labour, defined as a supply shock and labour market processes, do not have to be so very obvious, as predicted by the basic models of the labour market'.
}

Another explanation argues that the departure of unemployed and under-employed people reduces the need for housing and makes other social provisions more available to the stayers, including welfare (Austers, 2015). Evidence from individual CEE countries shows however that a substantial proportion of migrants were employed prior to their departure (cf. Kaczmarczyk, 2018; Hazans, 2013). For instance, among those who left Poland in the first phase after 2004 EU enlargement, 50 per cent had stable jobs before departure, 25 per cent were unemployed, and 14 per cent were inactive (Kaczmarczyk and Okólski, 2008). Those who left Latvia (Hazans, 2013) were predominately employed before departure, between 80 and 90 per cent. This suggests that wage differences mattered much more than employment opportunities (Austers, 2015).

Martin and Radu (2012) collated EU-LFS for return migration in CEE countries and their labour market participation. They showed that return migrants are less likely to actively participate in the labour market, even though they earn a wage premium for work experience abroad (10-45 per cent); instead, they go for self-employment. Return migrants to CEE countries are also more likely to have spells of unemployment during the first year after return.

To summarise, if we look at classical economic indicators, we see on the one hand that GDP gains are unequally distributed between sending and receiving countries. On 
the other hand, local sending economies both directly and indirectly receive money from the $\mathrm{EU}$ in the form of economic remittances and EU Funds, the combination of which can eventually compensate for the negative economic effects in the long run. It depends however on earlier economic adjustments which took place during the pre-EU enlargements system transitions processes in the individual CEE countries. We also see that wage differences and the purchasing power of money have been much more important for migrants than sending local employment opportunities - predominantly employed people have undertaken intra-EU mobility.

\section{Social impact}

The interrelated socio-economic effects of the EU enlargements are clearly recognisable when one considers the total human capital approach (Hagan et al., 2015), followed by social remittances (Levitt, 1998) and the social mobility of migrants. Therefore the effects of migration on human capital should be analysed in relation to both tangible (educational attainment, formal qualifications, work experience) and intangible (social skills, competences, well-being) components. It is also important to consider the above-mentioned economic remittances in relation to social remittances, i.e. the transfer and circulation of all non-financial resources such as norms, values, practices, ideas, social capital (Levitt, 1998), knowledge and skills (Grabowska and Garapich, 2016a; Grabowska et al., 2017; Grabowska, 2018a, 2018b). While discussing the effects of migration, especially on migrants themselves, from the perspective of sending countries, it is important to consider social mobility; not with reference to natives in a receiving country as it has usually been done, but in relation to stayers in the relevant sending country (e.g. Grabowska, 2016a; Masso et al., 2013).

Discussions of the impact of migration on the human capital of CEE migrants often involve the concepts of brain flow as well as brain drain and brain squandering. In some countries - primarily the Baltic States - emigration has achieved an enormous scale in relation to the size of their population and it is reported that they might lose a whole generation who was under twenty-five during the first years of enlargement (Thaut, 2009; Austers, 2015). As in the case of Poland, migration is highly selective by region, gender, age and education; the analysis by Anacka and Okólski (2010) showed that the relative losses were remarkable, with the population of certain groups - especially people between the ages of twenty and twenty-nine - having been reduced by as much as a quarter. There is also a group of young people who immediately take their first job abroad upon completing their education, without even trying their chances in their country of origin: 30 per cent in local surveys in Poland in 2007 (Grabowska, 2016b). The outflow of medical specialists from Romania (e.g. Tilea et al., 2013), the Baltic States and Slovakia, especially, is perceived as one of the biggest 'losses' (Bélorgey et al., 2012: 4). In the case of Poland, the outflow of medical specialists is not perceived as a national mass phenomenon (Kaczmarczyk, 2013), but might affect local health institutions.

From some of the national censuses and research in the receiving countries, we know that large groups of persons who migrated after 2004 and 2007 from post-communist countries work below their formal qualifications, indicating mismatches between their qualifications, occupations and jobs held in the destination countries (e.g. Currie, 2007; Grabowska-Lusinska and Okólski, 2009; Nowicka, 2012, 2014; Voitchovsky, 2014). In the case of Polish migrants, one in three individuals in the total migrating population and 
one in two migrants with third-level education who left Poland after the EU enlargement in May 2004 had jobs for which they were overqualified based on their formal qualifications (Statistics Poland, 2013). This has to do both with the nature of the labour markets in the $\mathrm{EU}$, which predominately acknowledge national recognition of qualifications, limited access to certain occupations, bureaucracy and host country language competences (cf. Dustmann, 1999) and ability of people to accept lower status jobs as they still pay more than jobs in home countries.

There are various lines of explanation that involve the concept of brain flow from CEE. According to Galgóczi and Leschke (2012), the 2004 and 2007 enlargements did not improve the distribution of human capital between East and West, due to the qualification and population losses in the sending countries. On the contrary, it has, in their opinions, led to a waste of human resources in the form of both classical brain drain and brain squandering. Galgóczi et al. (2011) especially stress the youth drain both in Poland and Latvia. Kaczmarczyk and Okólski (2008) claim that if we take into account the selectivity of migration and local and regional labour market conditions, a significant share of the outflow may be regarded as a phenomenon of brain overflow, rather than brain drain, with the caveat that the EU enlargements are the outcomes of a set of public policies to balance various resources in the EU.

Another line of explanation relates to the impact of migration on the intangible human capital of CEE migrants. Baláž and Williams (2004) and Williams and Baláž (2005) first showed the importance of tacit skills in human capital transfers in their analysis of various groups of skilled return migrants to Slovakia: professionals, managers, students and au pairs. In particular, they highlighted language and communication skills, which can be transferrable in the global world, interpersonal skills and self-confidence and, especially, social recognition. In their research, many migrants expressed that migration had changed their perspectives, self-awareness and self-confidence.

Grabowska (2018b) in White et al. (2018) showed that although large numbers of highly educated Polish migrants were downgraded in the host labour markets in terms of their formal qualifications, they were able to improve their social skills, particularly with regard to communicating and acting in socially diverse environments. Based on both the extensive data set of Human Capital in Poland 2010-2014 and qualitative findings, they demonstrated that working abroad for more than three months impacts on social skills (cognitive, intrapersonal and interpersonal), and that this impact grows with the generational age cohorts: the longer a migrant has lived under communism, the more their social skills are impacted by international migration.

Most other social effects are best considered at meso (local community) and micro (family, individuals) levels (Faist, 2016). Elrick (2008) found out that migration has become the main vehicle for social mobility and the main strategy for escaping from social deprivation. Resources from migration both tangible and intangible helped people to raise their social status in local social strata. Masso et al. (2013) analysed the impact of the temporary migration of Estonians on their social mobility. They used data from an Estonian online job search portal covering approximately 10-15 per cent of the total workforce. They did not find any positive effect of temporary migration on upward social mobility, and, for women, the effect was even negative. As the authors point out, these results may be related to the predominantly short-term nature of migration from Estonia and occupational downshifting abroad as well as to the structure of the domestic labour market. 
Grabowska (2016a) argues that in order to see the effect of migration on a sociooccupational path, a reference population of stayers is needed. The effects of migration also differ in relation to the form of migration: seasonal or non-seasonal, repeated or single. She found out that migration impacts on the career sequences brings more dynamics in work life as compared to stayers, along with both upward mobility (nearly 20 per cent of researched migrants) as well as downward mobility (14 per cent of researched migrants).

In addition to economic remittances, people also transfer or circulate non-financial resources obtained through migration: norms, values, practices, ideas, and social capital captured as social remittances (Levitt, 1998). Through social remittances, migration can alter socio-economic structures in the origin country: social class and ethnic hierarchies, traditional care arrangements, family structures, gender relations, cultures of migration, and entrepreneurship (Kaczmarczyk, 2013). Social remittances were mostly studied in a non-European context between developed and developing countries. However there are emerging studies showcasing the impact of social remittances in the CEE countries (Sandu, 2010; Grabowska and Garapich, 2016a; Krzyżowski, 2016; White, 2016; Grabowska et al., 2017).

Sandu's (2010) survey analysis in Romania covered micro (personal and household) and meso (community) social effects of migration. The first order effects that he found included an increase in financial resources and social capital and a 'modernisation of values', showed higher consumption, entrepreneurship and modernised family behaviours as second-order consequences. The analysis discussed the improvement of housing, the development of private sectors and demographic effects such as increasing divorce rates and declining birth rates as third order effects. He concluded that migrants are modern risk-takers who introduce values relating to the importance of work, secularism, life success and leisure time into their communities. They are 'modern person', which manifests as 'openness to new experiences', time planning, and a positive attitude towards technological innovations. Return migrants assessed that working abroad was a way to change their own view on work, life strategies, quality and use of time and sociability, as compared to stayers (Sandu, 2010).

A general survey among Polish society revealed that persons with migration experience evaluate their opportunities in the Polish labour market more positively than non-migrants, are more self-confident, open-minded and ready to accept different lifestyles and are relatively critical of religious and political authority. Data shows that social remittances are fairly limited social phenomena, but effects may be visible in the longer term (Kaczmarczyk, 2013).

The social effects of migration on local communities were studied in the 1990s and early 2000s, mostly in Poland (Jazwinska and Okólski, 2001; Elrick, 2008; Okólski, 2012), with incomplete migration as a predominating pattern ${ }^{8}$. Contemporary studies on the social effects of migration on CEE local communities mostly relate to social remittances (for Poland: Grabowska et al., 2017) and connect with them migration-development nexus ${ }^{9}$ (for Romania: Cucuruzan, 2008; discussion for Poland: Grabowska and Garapich, 2016a; White et al., 2018).

In recent decades, studies in communities with a long migration history and a high volume of outflow have shown that the factory and post-coop cultures of local communities seems to have been replaced by a 'migration culture' (cf. Massey et al., 1993), especially in places where incomplete migration patterns still persist (Okólski, 2012). In 
this line Elrick (2008) also find out that the impact of migration on origin communities is dependent on the intensity and temporality of migration as well as the type of migration. Those communities who experienced rather intense migration with regular employment abroad are more able to impact local normative structures and bring back values and goods than those whose members primarily engaged in temporary, undocumented migration.

Grabowska and Garapich (2016a) and Grabowska et al. (2017) studied social remittances between UK and three selected local communities in Poland with different histories, system transition paths and migration history. They found that individual migrants themselves are the missing link in the 'migration-social change nexus' of local communities. The money obtained through European Structural Funds for developing road infrastructure, public spaces, office spaces is not enough for social changes in local communities to happen without a change in mentality of local actors, which may be in part be effected by migration. Return migrants themselves might bring both social remittances of innovation and social remittances relating to nuanced multiculturalism and racism (Gawlewicz, 2015), which may take the form of selective tolerance but also stronger conservatism (preservation of traditional nature of local community). All cases show that the outcomes of leaving the homogeneous contexts of Polish local communities and encountering socially diverse environments endow migrants with new social skills.

To summarise, we see that EU enlargements have made certain contributions to the social and cultural make-up of CEE local societies both in terms of total human capital and through mechanisms of social remittances, but the migratory outcomes depend on local opportunity structures and earlier migratory experiences and traditions of local inhabitants. Social effects are well seen, however, alongside the economic impacts and as complementary to top-down EU public policies relating to four freedoms (if they include return mobility) and redistribution of EU Funds.

\section{Conclusions}

In this article we have considered the EU enlargements towards CEE countries as an outcome of a set of public policies with special focus on its distribution and redistribution functions in an interplay of its top-down and bottom-up developments. This approach allowed us to present, under one umbrella, a plethora of explanations on the socioeconomic effects of migration on sending countries and migrants themselves. We must remember, however, that EU enlargements do not happen in economic and social voids and we cannot separate their effects from the post-communist system transition adjustment processes which CEE countries and societies have been undergoing since the breakdown of communist rule at the beginning of 1990s.

In Table 2, we summarise the effects of EU enlargements on sending countries with respect to research uncertainties, gaps and consensus.

The analysis of arguments presented in this article might translate into the following policy implications. Firstly, while looking at the impact of migration caused by the EU enlargements on human capital, the total human capital of both tangible and intangible components needs to be taken into account. Employers could be provided with the instruments required to recognise social, soft skills and competences impacted by work abroad, instead of focusing only on formal certified qualifications. The new ESCO ${ }^{10}$ classification recognised by employers with the help of e.g. the Public Employment 
Table 2 The impact of post-enlargement EU mobility on CEE sending countries: research uncertainties, gaps and consensus

\begin{tabular}{|c|c|c|}
\hline $\begin{array}{l}\text { Research } \\
\text { uncertainties }\end{array}$ & Research gaps & Research consensus \\
\hline $\begin{array}{l}\text { The impact on GDP } \\
\text { in sending } \\
\text { countries }\end{array}$ & \multirow{2}{*}{$\begin{array}{l}\text { Knowledge and indicators of the } \\
\text { economic and social effects on } \\
\text { sending countries are not } \\
\text { evenly studied across CEE } \\
\text { countries - highest focus on } \\
\text { Poland and Baltic States }\end{array}$} & $\begin{array}{l}\text { Sending countries' labour market } \\
\text { effects range from neutral to low } \\
\text { positive, from a long-term } \\
\text { perspective }\end{array}$ \\
\hline $\begin{array}{l}\text { The impact of } \\
\text { economic } \\
\text { remittances on }\end{array}$ & & $\begin{array}{l}\text { Wage premium for return } \\
\text { migrants }\end{array}$ \\
\hline sending countries & \multirow{6}{*}{$\begin{array}{l}\text { The relations between macro- } \\
\text { meso-micro effects of migration } \\
\text { remain unclear and } \\
\text { understudied, especially } \\
\text { findings on the regional effects } \\
\text { of outflow still remain scattered } \\
\text { across CEE countries }\end{array}$} & No export of unemployment from \\
\hline $\begin{array}{l}\text { Brain flow, brain } \\
\text { drain and brain } \\
\text { squandering }\end{array}$ & & $\begin{array}{l}\text { labour markets of sending } \\
\text { countries; mostly employed } \\
\text { people left }\end{array}$ \\
\hline \multirow[t]{4}{*}{$\begin{array}{l}\text { The impact of } \\
\text { geographical } \\
\text { mobility on social } \\
\text { mobility }\end{array}$} & & $\begin{array}{l}\text { Positive impact on intangible } \\
\text { human capital despite some } \\
\text { downgrading of formal human } \\
\text { capital (qualifications) in } \\
\text { destinations }\end{array}$ \\
\hline & & $\begin{array}{l}\text { Social remittances more positive } \\
\text { than negative }\end{array}$ \\
\hline & & $\begin{array}{l}\text { No impact of so-called migration } \\
\text { for welfare only }\end{array}$ \\
\hline & & $\begin{array}{l}\text { The interplay of European } \\
\text { Structural Funds and economic } \\
\text { remittances in local economies } \\
\text { and labour markets. }\end{array}$ \\
\hline
\end{tabular}

Source: own elaboration

Services and EURES Network while employing return migrants might be of help in changing the policies relating to human capital allocations and developments, especially in the context of its rapidly aging populations of CEE societies. Secondly, the redistribution of EU Funds, as shown in this article, might well complementarily stand along the outcomes of free mobility of people and capital (economic and social remittances), should be better linked with the regulation function of EU enlargement connected to adopted acquis communautaire ${ }^{11}$ by CEE sending countries upon EU enlargements.

The decade and a half after the biggest historical expansion of the EU towards the CEE countries in May 2004 we enter the new 'settled phase' with rather steady dynamics of intra-EU mobility flows but Brexit and the next structural events to come might bring us to the new reality of return mobility. 


\section{Acknowledgments}

I would like to acknowledge my special thanks to Professor Anne White from University College London for her valuable comments to this article. The article is a follow up of the Annual Social Policy and Society lecture delivered by Izabela Grabowska on the $18^{\text {th }}$ of April 2018 at University of Sheffield. This article is also a part of the international research project CEEYouth: The comparative study of young migrants from Poland and Lithuania in the context of Brexit (DAINA 1, National Science Centre Poland and Research Council of Lithuania; contract no. 2017/27/L/HS6/03261).

\section{Notes}

1 EU 8: The Czech Republic, Estonia, Hungary, Latvia, Lithuania, Poland, Slovakia and Slovenia.

2 Bulgaria and Romania.

3 Czech Republic, Estonia, Cyprus, Latvia, Lithuania, Hungary, Malta, Poland, Slovakia and Slovenia.

4 Eight Accession Countries: The Czech Republic, Estonia, Hungary, Latvia, Lithuania, Poland, Slovakia and Slovenia.

5 The Worker Registration Scheme (WRS) was introduced in May 2004 to regulate access to the labour market of migrants from the Accession 8 countries (Czech Republic, Estonia, Hungary, Latvia, Lithuania, Poland, Slovakia and Slovenia) and to restrict their access to benefits (accessed 29/12/2019: https://migrationobservatory.ox.ac.uk/about/data-sources-limitations/worker-registration-scheme/).

6 A posted worker is an employee who is sent by his employer to carry out a service in another EU Member State on a temporary basis, in the context of a contract of services, an intra-group posting or a hiring out through a temporary agency (accessed 29/12/2019: https://ec.europa.eu/social/main.jsp? catld $=471$ ).

7 The ten countries that joined the EU in 2004: Cyprus, the Czech Republic, Estonia, Hungary, Latvia, Lithuania, Malta, Poland, Slovakia and Slovenia.

8 Incomplete migration was formed as a substitutive pattern of migration to rural-urban migration which in communist Poland meant commuting from farms to big industrial communist plants. When communism collapsed and factories were shut down, similar behaviours were transplanted to the grounds of international migration, mostly to neighbouring countries (Okólski, 2001).

9 Migration and development are two complex and interrelated issues. While migration is frequently caused by underdevelopment, it may also present a vehicle to foster development and a means of escape from poverty (Van Hear and Sorensen, 2003, for IOM).

10 ESCO (European Skills, Competences, Qualifications and Occupations) is the European multilingual classification of Skills, Competences, Qualifications and Occupations; available at: https:// ec.europa.eu/social/main.jsp?catld=1326\&langld=en (accessed 26/7/2019).

11 Acquis communautaire is a French term referring to the cumulative body of European Community laws, comprising the EC's objectives, substantive rules, policies and, in particular, the primary and secondary legislation and case law - all of which form part of the legal order of the European Union (EU). This includes all the treaties, regulations and directives. The acquis is dynamic, constantly developing as the Community evolves, and fundamental. All Member States are bound to comply with the acquis communautaire (accessed on 02/01/2020 at: https://www.eurofound.europa.eu/observatories/eurwork/industrialrelations-dictionary/acquis-communautaire).

\section{References}

Anacka, M. and Okólski, M. (2010) 'Direct demographic consequences of post-accession migration for Poland', in R. Black, C. Pantîru, M. Okólski and G. Engbersen (eds.), A Continent Moving West?, Amsterdam: Amsterdam University Press, 141-64. 
Aranson, P. H. and Ordeshook, P. C. (1981) 'Regulation, redistribution, and public choice', Public Choice, $37,1,69-100$.

Austers, A. (2015) The Economic Impact of Intra-EU Mobility of People on the Destination and Sending Countries. Review of Relevant Research Papers, Conference, 11-12 May, Riga.

Baláž, V. and Williams, A. M. (2004) "Been there, done that': international student migration and human capital transfers from the UK to Slovakia', Population, Space and Place, 10, 3, 217-37.

Barbone, L., Pietka-Kosinska, K. and Topinska I. (2012) Wpływ przepływów pieniężnych na polską gospodarkę w latach 1992-2012 - raport Western Union, przygotowany przez Centrum Analiz Społeczno-Ekonomicznych - CASE, Warsaw: CASE \& Western Union.

Barslund, M., Busse, M. and Schwarzwälder, J. (2015) 'Labour mobility in Europe: an untapped resource?', CEPS Studies Policy Brief No. 327, Centre of European Policy Studies Policy.

Beblavý, M., Maselli, I. and Veselková, M. (2014) Let's Get to Work! The Future of Labour in Europe, Brussels: Center for European Policy Studies.

Bélorgey, N., Garbe-Emden, B., Horstmann, S., Kuhn, A, Vogel, D. and Stubbs, P. (2012) Social Impact of Emigration and Rural-Urban Migration in Central and Eastern Europe, European Union, Synthesis Report, GVG, Köln, VT/2010/001.

Bodvarsson, Ö. B. and Van den Berg, H. (2009) The Economics of Immigration. Theory and Policy, Springer.

Castles, S. and Miller, M. J. (2003) The Age of Migration, International Population Movements in the Modern World, 3rd edn, New York, London: The Guilford Press.

Cucuruzan, R. E. (2008) 'The labour migration-development nexus. The case of two rural communities in Romania', Romanian Journal of Population Studies, 2, 24-44.

Currie, S. (2007) 'De-skilled and devalued: the labour market experience of Polish migrants in the UK following EU enlargement', International Journal of Comparative Labour Law and Industrial Relations, 23, 83-116.

D'Auria, F., Mc Morrow, K. and Pichelmann, K. (2008) 'Economic impact of migration flows following the 2004 EU enlargement process: a model based analysis', European Economy, Economic Papers, No. 349.

Dustmann, C. (1999) 'Temporary migration, human capital, and language fluency of migrants', Scandinavian Journal of Economics, 101, 2, 297-314.

Elrick, T. (2008) 'The influence of migration on origin communities: insights from Polish migrations to the West', Europe-Asia Studies, 60, 9, 1503-17.

Engbersen, G. and Jansen J. (2013) 'Emigration from the Baltic States: economic impact and policy implications', in Coping with Emigration in Baltic and East European Countries, OECD Publishing.

Engbersen, G., Leerkes, A., Scholten, P. and Snel, E. (2017) 'The intra-EU mobility regime: differentiation, stratification and contradiction', Migration Studies, 5, 3, 337-55.

Faist, T. (2016) 'Social mechanisms in local transformations: towards a conclusion', Population, Space and Place, 22, 4, 396-401.

Fassmann, H., Kohlbacher, J. and Reeger, U. (2014) 'The re-emergence of European East-West Migration: the Austrian example, Central and Eastern European Migration Review, 3, 2, 39-59.

Fihel, A. and Grabowska-Lusinska, I. (2014) 'Labour market behaviours of back-and-forth migrants from Poland, International Migration, 52, 1, 22-35.

Fihel, A., Janicka, A. and Kloc-Nowak, W. (2018) 'The direct and indirect impact of international migration on the population ageing process: a formal analysis and its application to Poland', Demographic Research, 38, 1303-38.

Fihel, A., Kaczmarczyk, P. and Okólski, M. (2006) Labour Mobility in the Enlarged European Union: International Migration from the EU8 Countries (No. 14/72), CMR working papers.

Galgóczi, B. and Leschke, J. (2012) Intra-EU labour migration after Eastern Enlargement and during the crisis', Working Paper 2012.13, European Trade Union Institute.

Galgóczi, B., Leschke, J. and Watt, A. (2011) 'Intra-EU labour migration flows, effects and policy responses, Working Paper 2009.03, Brussels: European Trade Union Institute. 
Gawlewicz, A. (2015) "We inspire each other, subconsciously": the circulation of attitudes towards difference between Polish migrants in the UK and their significant others in the sending society', Journal of Ethnic and Migration Studies, 41, 13, 2215-34.

Geddes, A. (2003) 'Migration and the welfare state in Europe', The Political Quarterly, 74, 1, 150-62.

Gjini, A. and Moisiu, A. (2013) 'The role of remittances on economic growth: an empirical investigation of 12 CEE countries', International Business and Economic Research Journal, 12, 2, 193-204.

Goschin, Z. (2014) 'Remittances as an economic development factor. Empirical evidence from the CEE countries', Procedia Economics and Finances, 10, 54-60.

Grabowska, I. (2016a) Movers and Stayers: Social Mobility, Migration and Skills, Frankfurt Am Main: Lang.

Grabowska, I. (2016b) The transition from education to employment abroad: the experiences of young people from Poland, Europe-Asia Studies, 68, 8, 1421-40.

Grabowska, I. (2018a) 'Social skills, workplaces and social remittances: a case of post-accession migrants', Work, Employment and Society, 32, 5, 868-86.

Grabowska, I. (2018b) 'Social remittances: channels of diffusion', in A. White, I. Grabowska, P. Kaczmarczyk and K. Slany (2018) The Impact of Migration on Poland: EU Mobility and Social Change, London: UCL Press, 68-89.

Grabowska, I. and Engbersen, G. (2016) 'Social remittances and the impact of temporary migration on an EU sending country: the case of Poland', Central and Eastern European Migration Review, 5, 2, 99-117.

Grabowska, I. and Garapich, M. P. (2016a) 'Social remittances and intra-EU mobility: non-financial transfers between UK and Poland', Journal of Ethnic and Migration Studies, 42, 13, 2146-62.

Grabowska, I. and Garapich, M. (2016b) 'Mapping social remittances and 'segmented development' in Central and Eastern Europe', Central and Eastern European Migration Review, 5, 2, 5-13.

Grabowska, I., Garapich, M., Jazwinska, E. and Radziwinowiczówna, A. (2017) Migrants as Agents of Change. Social Remittances in and Enlarged EU, Basingstoke/London: Palgrave Macmillan.

Grabowska-Lusinska, I. and Okólski M. (2009) Emigracja ostatnia?, Warsaw: Scholar.

Grzymala-Kazlowska, A. (2013) 'Migration and socio-demographic processes in Central and Eastern Europe: characteristics, specificity and internal differences', Central and Eastern European Migration Review, 2, 1, 5-11.

Hagan, J., Hernández-León, R., Hernández-León, R. and Demonsant, J. L. (2015) Skills of the Unskilled: Work and Mobility among Mexican Migrants, Univ of California Press.

Hazans, M. (2013) 'Emigration from Latvia: recent trends and economic impact', in Coping with Emigration in Baltic and East European Countries, OECD Publishing, 65-110.

Holland, D., Fic, T., Rincon-Aznar, A., Stokes, L. and Paluchowski, P. (2011) 'Labour mobility within the EU - The impact of enlargement and the functioning of the transitional arrangements', National Institute of Economic and Social Research, Final Report.

Iglicka, K. (2001) 'Migration movements from and into Poland in the light of East-West European migration', International Migration, 39, 1, 3-32.

Jażwińska, E. and Okólski, M. (eds.) (2001) Ludzie na hustawce: migracje między peryferiami Polski i Zachodu, Warsaw: Scholar.

Kaczmarczyk, P. (2018) 'Post-accession migration and the Polish labour market: expected and unexpected effects', in A. White, I. Grabowska, P. Kaczmarczyk and K. Slany (eds.), The Impact of Migration on Poland: EU Mobility and Social Change, London: UCL Press.

Kaczmarczyk, P. (2013) 'Matching the skills of return migrants to labour market needs in Poland', in Coping with Emigration in Baltic and East European Countries, Paris: OECD Publishing, 112-26.

Kaczmarczyk, P. and Okólski, M. (2008) 'Demographic and labour-market impacts of migration on Poland', Oxford Review of Economic Policy, 24, 3, 599-624.

Kahanec, M., Zaiceva, A. and Zimmermann, K. F. (2009) 'Lessons from migration after EU enlargement', in M. Kahanec and K. F. Zimmermann (eds.), EU Labour Markets after Post-Enlargement Migration, Springer, 3-46. 
Krisjane, Z., Apsite-Berina, E. and Berzins, M. (2016) 'Circularity within the EU: the return intentions of Latvian migrants', in Return Migration and Regional Development in Europe, London: Palgrave Macmillan, 215-40.

Krzyżowski, Ł. (2016) 'Structuring social remittances: transnational networks of Polish migrants', in Migration and Social Remittances in a global Europe, London: Palgrave Macmillan, 71-93.

Kurekova, L. (2013) 'Welfare systems as emigration factor: evidence from the new Accession states', Journal of Common Market Studies, 51, 4, 721-39.

Layard, R., Blanchard, O., Dornbush, R. and Krugman, P. (1994) East-West Migration: The Alternatives, Cambridge, MA: MIT Press.

Levitt, P. (1998) 'Social remittances: migration driven local-level forms of cultural diffusion', International Migration Review, 32, 4, 926-48.

Markova, E. (2010) 'Optimising migration effects: a perspective from Bulgaria', in R. Black, G. Engbersen, M. Okólski and C. Pantiru (eds) A Continent Moving West? EU Enlargement and Labour Migration from Central and Eastern Europe, Amsterdam: Amsterdam University Press, 207-30.

Martin, R. and Radu, D. (2012) 'Return migration: the experience of Eastern Europe', International Migration, 50, 6, 109-28.

Massey, D. S., Arango, J., Hugo, G., Kouaouci, A., Pellegrino, A. and Taylor, J. E. (1993) 'Theories of international migration: a review and appraisal', Population and Development Review, 431-66.

Masso J., Eamets, R. and Motsmees, P. (2013) The Effect of Migration Experience on Occupational Mobility in Estonia, The University of Tartu FEBA.

Mereuta, C. (2012) Mobilising Migrants Skills and Resources- The Case of Romania, paper presented for the international conference, Latvian Ministry of Foreign Affairs and the OECD, December 17, Riga.

Newell, W. H. (1998) 'Professionalizing interdisciplinarity: a literature review and research agenda', in W. H. Newell (ed.), Interdisciplinarity: Essays from the Literature, New York: The College Board, 529-63.

Nowaczek, K. (2010) 'Pressure of migration on social protection systems in the enlarged EU', in R. Black, G. Engbersen, M. Okólski and C. Pantiru (eds.), A Continent Moving West? EU Enlargement and Labour Migration from Central and Eastern Europe, Amsterdam: Amsterdam University Press, 289-312.

Nowicka, M. (2014) 'Migrating skills, skilled migrants and migration skills: the influence of contexts on the validation of migrants' skills', Migration Letters, 11, 2, 171-86.

Nowicka, M. (2012) 'Deskilling in migration in transnational perspective: the case of recent Polish migration to the UK', COMCAD Working Papers, 112. Bielefeld: Universität Bielefeld, Fak. für Soziologie, Centre on Migration, Citizenship and Development.

OECD (2006) 'International migrant remittances and their role in development', in International Migration Outlook: SOPEMI 2006 Edition, Paris: OECD.

Okólski, M. (ed.) (2012) European Immigrations: Trends, Structures and Policy Implications, Amsterdam University Press.

Okólski, M. (2004) 'Migration patterns in Central and Eastern Europe on the eve of the European Union enlargement', in A. Górny and P. Ruspini (eds.), Migration in the New Europe. East-West Revisited, Houndmills, Basingstoke, Hamshipre: Palgrave Macmillan, 23-48.

Okólski, M. (2001) Mobilność przestrzenna z perspektywy koncepcji migracji niepełnej, Ludzie na hustawce: Migracje między peryferiami Polski i Zachodu, 31-61.

Okólski, M. and Salt, J. (2014) 'Polish emigration to the UK after 2004; why did so many come?', Central and Eastern European Migration Review, 3, 2, 11-37.

Repko, A. and Szostak, R. (2017) Interdisciplinary Research: Process and Theory, Thousand Oaks: Sage. Sandu, D. (2010) 'Modernising Romanian society through temporary work abroad', in R. Black, G. Engbersen, M. Okólski and C. Pantiru (eds.), A Continent Moving West? EU Enlargement and Labour Migration from Central and Eastern Europe, Amsterdam: Amsterdam University Press, 271-87.

Scholten, P. and Van Ostaijen, M. (2018) Between Mobility and Migration. The Multi-Level Governance of Intra-European Mobility, IMISCOE Research Series, Cham: Springer. 
Statistics Poland (2013) Migracje zagraniczne ludności. Narodowy Spis Powszechny Ludności i Mieszkan 2011. Warszawa: Główny Urząd Statystyczny.

Taylor-Gooby, P. (1996) The response of government: fragile convergence?, in V. George and P. TaylorGooby (eds) European Welfare Policy. Squaring the Welfare Circle, Houndmills: Macmillan, 199-218.

Thaut, L. (2009) 'EU integration and emigration consequences: the case of Lithuania', International Migration, 47, 1, 191-233.

Tilea, B., Vasile, V. and Tilea, I. (2013) 'Labour force mobility and employment crisis in health care sector in Romania', Romanian Journal of Economics, 36, 1, 45.

Van Hear, N. and Sorensen, N. N. (eds.) (2003) The Migration-Development Nexus, Geneva: IOM International Organisation for Migration.

Vargas-Hernandez, J., Noruzi, M. R. and Ali, I. F. N. H. (2011) 'What is policy, social policy and social policy changing?', International Journal of Business and Social Science, 2, 10, 287-91.

White, A. (2016) 'Social remittances and migration (sub)-cultures in contemporary Poland', Central and Eastern European Migration Review, 5, 2, 63-80.

White, A., Grabowska, I., Kaczmarczyk, P. and Slany, K. (2018) The Impact of Migration on Poland: EU Mobility and Social Change, London: UCL Press.

Wieruszewska, M. (2010) (ed.) Tu i tam: migracje z polskich wsi za granicę, Warsaw: IRWiR.

Williams, A. M. and Baláž, V. (2005) 'What human capital, which migrants? Returned skilled migration to Slovakia FROM the UK', International Migration Review, 39, 2, 439-68.

World Bank (2006) World Development Indicators, Washington, DC.

Veselková, M., van der Gaag, N., Boiter, B., Lancesseur, N. and Zagamé, P. (2014) 'How much work will there be? Where is it going to come from?', in M. Beblavý, I. Maselli and M. Veselková (eds.), Let's Get to Work! The Future of Labour in Europe, Centre of European Policy Studies, 1, 29-55.

Voitchovsky, S. (2014) 'Occupational downgrading and wages of new member states immigrants to Ireland', International Migration Review, 48, 2, 500-37. 